\title{
Professional Mobility and "Objective" and "Subjective" Satisfaction. a Non- Linear Analysis from the Theory of the Three-Dimensional Spiral of Sense in Population of Doctors
}

\author{
PhD. Miriam Aparicio \\ National Council of Scientific Research (CONICET); \\ National University of Cuyo. Mendoza, Argentina
}

\begin{abstract}
This work goes along the lines of the author's research (1995-2016) on professional careers and models bearing causes and effects regarding sustained interaction (core, psychosocial, institutional and structural factors). The aim of this paper was analyze, through the doctors' social representations, the levels of satisfaction evidenced by those who have advanced professionally to the highest positions within the scientific (or other) system. The hypothesis states that the relation is not linear but inverse. Satisfaction would not increase according to the Professional Status. We consider here, on the one hand, the insufficient Professionalization and the increasing demands from the market; and on the other, the impact structural limits have on the micro level. The methodology used was quanti-qualitative (semi-structured questionnaires, interviews, and hierarchical evocations). The population consisted of doctors (2005-2012) from the National University of Cuyo, in Argentina and the Cnam (France) of different courses of study. The results confirm the hypothesis. As regards what was observed among those who advanced professionally, the increase on the growing market demands along with the lack of institutionalized means in order to reach goals, result in lower satisfaction. This is interpreted from the theory of the author, which involves 3 levels (macro-meso-micro-macro) (Aparicio, $2015 \mathrm{a}, \mathrm{b}$ ). We also consider the theories of anomie and of the expectancy of valence (Feather \& Davenport). Findings along this line were also seen in studies with scientists (Aparicio, 2014). The results propose a revision in the prevailing working conditions and police: satisfaction acts on subsystems and consolidates them.
\end{abstract}

Keyswords: Professional Mobility - Status Professional - Professional Satisfaction - Social Representations - Labor Market

\section{General Introduction: Epistemological Support}

This article refers to the theory or, if someone prefers, pre-theory is the result or synthesis of the principal research works done within the CONICET (National Council of Scientific Research) and since 1995 the Argentine Ministry of Education, Science and Technology, with individuals belonging to different populations, some of them covering periods of over 20 years (intra-generational studies), and others covering three generations in-line (inter-generational studies). It is called the Theory of the Three-Dimensional Spiral of Sense. It develops out of studies carried out on six disciplinary areas in which the new analysis of the social data was carried out: Education, Health, Science, Media, International Relations and Interculturality. As far as we are concern here, the first area - Education - is dealt with through different levels (secondary level, tertiary level, University and $\mathrm{PhD}$ training).It is, especially, in a second stage of the research developed since 1995 along the lines of Social, Labor and Organizational Psychology,in which I focus on the relation between Achievement at University and at Work, and their mutual sustained interaction and on the relation to several factors and/or quantitative dimensions which act as conditioning reasons/causes of said Achievement (Rosen,1956; McClelland,1961, 1970). Throughout this long period, the problem of socio-professional Mobility in relation to Education/Formation, is a core issue. My interest grew stronger, particularly in connection with the analysis of the impact (explanatory/quantitative level) and comprehension (qualitative level) of the psychosocial factors on achievement within the context of the international patterns related to Quality Assessment at University in its connection with the scientific and productive systems (for a case reference, see Aparicio, 2014 b, 2015 a CROS and b). It should be noticed that the prevailing criteria for quality assessment are efficiency, political effectiveness, efficacy and relevance. However, due to the difficulties regarding the interactive analysis 
of the answers provided by the university system to the needs of the socio-productive and scientific world, this last criterion - the core issue in our studies - was mostly overlooked at the international level.

It should be mentioned here that this Assessment was started late in Argentina, in 1995, when the University Quality, combined with context, is first considered a priority. University polices emphasize the need to reach systemic analyses. However, Assessment comes down to figures, statistics, diagnoses, inputs and ouputs, but the human processes, which lie at the base of such figures, remain unknown in the Argentine system and, more globally, within the international framework, as it has been commonly pointed out literature until these days. As regards this issue, since the publication of L'inégalité des chances (1973), translated by Aparicio (1983), R. Boudon, one of the methodological mainstays in my research, despite our differences, urges us to work on this kind of patterns, which in 2004 were yet nonexistent, as he himself stated in one of his latest works.

It was a challenge to implement a systemic analysis of the factor with an impact on achievement at the macro level, and of the impact of the macro or micro organizational contexts on the individuals.

In this article, we will focus on the latest comparative studies (Argentine and France) carried out on populations of PhD students and doctors. It strictly analyses the relation between Professional Mobility, its impact on the rise in the organizational hierarchy, from the point of view of Professional Status reached and its relationship with Satisfaction. Such relation does not develop as a linear or correlating act. Satisfaction, as we will see, shows two faces: one deriving from Status Rise or Change, linked to Mobility, and a second face which we call "Subjective or Lived/Experienced Satisfaction" " (Hertzberg, Mausner \& Snyderman, 1959), linked to new demands of the new position within a context of increasing demands from the market. Said Satisfaction does not seem to be associated psychological or group Wellbeing. This leads to coin the term "experienced Satisfaction" (Aparicio, 2016).

\subsection{Objectives}

1. Being aware of the factors affecting professional achievement of doctors (French and Argentine) at the quantitative and qualitative levels.

2. Being aware and comparing (descriptive level) the sociological, psychosocial and institutional issues, taking into account that labor insertion is nowadays an international problem (general discomfort within training institutions at the moment of entering the labor market, and, later, labor organizations.

3. Analyze the relation between "lived" Satisfaction, and the Satisfaction which implies Professional Mobility (which generally involves reaching a higher Status in the organizational hierarchy).

4. Begin aware, through the representations shared by French and Argentine doctors, which psychological factors and/or dimensions (climate, leadership, etc.) are more associated to "subjective" Satisfaction, as we have decided to call it.

5. Analyze the similar and different factors among the doctors, which develop from different national and institutional contexts.

6. Providing those in charge of the educational sector (French and Argentine) with material for reflection in order to implement programs aiming at improving the quality of continuous training and, there before, labor insertion.

\subsection{Hypothesis}

-The relation between the levels of satisfaction evidenced by those who have advanced professionally to the highest positions within the scientific (or other) system is not linear.

-The relation between Satisfaction "subjective" would not increase according to the Professional Status.

- Psychosocial factors have a great influence on "lived" Satisfaction, besides The Professional Mobility and the status reached.

-The factors and/or dimensions which are favored according to the macro-national, meso organizational/institutional and micro-personal contexts differ. They show a self-sustained interplay. 


\section{Methodology}

The quantitative/ qualitative method was applied. This study refers only to the qualitative method.

\subsection{Participants}

Consisting of doctors in Education and other social sciences at Universidad Nacional de Cuyo (2005-2009), and doctors training in Adult Education at Cnam, Administration and Sociology (National Conservatory of Arts and Crafts) (France). Two research laboratories took part in this work- It is expected to find different profiles according to the work/professional contexts in which they are situated.

\subsection{Techniques}

Quantitative and qualitative techniques were applied. We use the "hierarchical evocation" (Aparicio \& Cros, 2015 a) and the lexicometric analysis techniques. Interviews were also conducted on each doctor/PhD student. The latter slowed to show which representations are part of de "nucleus" of a doctoral training in each of the national groups, and which are their most evident differences and the ways they experience their professional practice according to their expectations.

\subsection{Core questions of this research}

How and where are the doctors positioned within the market? Which professional structures are they in? Which are the aspects defining their actual insertion in terms of achievement (objective, subjective, hierarchical position)? What do they expect as regards their PhD training? Do the regard PHD training as a lever of progress? Which are the prioritized values and or factors/dimensions? Do the search for stability reality of the benefits related to a $\mathrm{PhD}$ degree? How do they envision their future? How do they see their role? Which are, from their own perspective, the factors currently prioritized by the market? Is there a lack of correspondence between their training and the market demands? Which prevails in the national groups, hope or pessimism? Finally, are their differences within the dimensions linked to "lived" Satisfaction according to Careers on both countries and Careers (meso level)? Do these doctors (French and Argentine) share specific "identities" and "interests"? What are their differences and similarities? (plano macro.) IDoes the level of Professionalization impact on such experience?

\section{Results}

We now present the results in relation to the objectives and hypotheses put forward

The qualitative analysis found that Satisfaction does not run parallel to Professional Status or to Professional Mobility. This leads Dr. Aparicio (2015a) to coin the term Subjective Mobility, and in this work, "Subjective" "Satisfaction", even though it may seem repetitive.

What does this mean?

One thing is Status, reached objectively, which in general terms implies a rise or Rising Professional Mobility in the professional Rank, being higher in Argentina, since the plafond effects or graduates oversaturation is less observed. The other face has to do with which involves such Mobility (not always accepted by the graduates). That is, the various implications of the new position, the widespread feeling that University did not teach many of the competences required (especially, collective and social ones), necessary material demands, but also those related to leadership (Aparicio 2002 a, 2014 a). Inadequate formation regarding "open mindedness" to favor internalization of a new "organizational subculture" and job-related values (Aparicio, 2002a; 2004a and b). The interviews also show - particularly within the group of doctors graduated in Management - organizational capacity and technology management problems; problems regarding recruiting and government competences required by the new demands, in addition to others associated to protecting human resources in their charge, to securing, through continuing training, uninterrupted employability of subordinates in order to promote and implement supporting programs for study-courses, etc. (Gilbert, 2003, 2004). These aspects are related to the psychosocial and organizational levels, on which Dr. Aparicio has been researching for the past 30 years, approaching them in a complementary fashion, as well as on their systemic interrelation (Aparicio, 2007 a and b; $2015 c$ and d, Theory of the Three-Dimensional Spiral of Sense). 
In other words, even though there was a certain generalized Satisfaction within our population, it did not appear with all its dimensions, and it showed some discomfort from the experiential point of view.

Let us expand on it. Many felt unhappy about the climate/atmosphere (Brunet \& Savoie, 1999; Rochon \& Courcy, 2006; Parker, Baltes, Young, Huff, Altmann, Lacost \& Roberts, 2003; Courcy, Harvey, Marceau, Rochon \& Belleau, 2006 ; Payne, 1973; ), about the quality of life at work and the new risks, about the demands of new management styles and human resources adapted to their respective socio-cultural, economical and political contexts (a developed country like Frances versus an emerging country, the category into which Argentine has stood for the last years after the so called "lost decades" and having been an international power). Other declared to have been trained for the organizational change (restructuring auditing, advising, consulting), for evaluating and promoting according to the competences required by the corporate sectors (in France, these processes are part of the Social Security Management of Competences [GEPC]. See. Aubret \& Gilbert, 1997; Gilbert, 2003, 2004, 2006).

Differences were also detected in connection with quality of life at work as regards the respective macro national and meso disciplinary contexts. Thus, many of the worries we pointed out appeared in the Management Courses in a more noticeable way that in Sociology and Education. These said to have problems associated to Training for Retraining, for evaluation, for designing programs aiming at employability against a growing unemployment which affects doctors too. (Giret, 2003; Calmand \& Haller, 2004; Dupray \& Moullet, 2004; Dupray, 2005; Giret, Moullet \& Thomas, 2003 ; Aparicio 2009 d, e, f).

Some even held that those rises threatened their health at work, such as longer hours, work load (dimension, temporality) and rhythmicity. Besides, the usual tensions experienced by managers shook their former security, their feeling of "being efficient" and "effective". Many felt they lost the "power" provided by their previous activity and that they were confronted to new complex learning situations. Such situations demanded, especially, decision-making and negotiation abilities - the so called "meta-competences" - ; competences to reach consensus and avoid conflict in their respective Departments or Areas of performance (Argyris \& Shon, 1974, 1978, 1996 a and b).

As for the rest, their expectations and dreams did not tally with the everyday professional practice; that is, there was a great difference, different according to courses of study, between organizational over-prescriptions and the competences to face them (Goffman, 1963). This aspect was more evident in Argentina, a country where University is still limited to disciplinary knowledge without focalizing on collective and social competences demanded by today's working world.

Among them, doctors mentioned the competences for controlling and improving dysfunctional behaviors (addictions, fraud, absenteeism, conflicts, ...); "management" and "management control" responsible for "Career Transition", for the retraining required today, for social responsibility,... All this, although some, who are "ideologically blinkered", considered responsibility to be "evil", which involves the Market in liberal societies. Some evil involving working harder, forsaking leisure and pleasure time in order to protect the interest of others' capital. (Henriquez,1976, 1989; Zarifian, 1988; Aubert \& Gaulejac, 1991; Reynaud, 1992; Louche, C., 1998; 1992; Luminet, 1996; Castra,1998; Cueillens, 1998; Chauvot ; 1997; Dubois, 1994 and particularly, Beauvais and his team, 1994 and subsequent works to Traité de la servitude libérale: Beauvois \& Joule, 1981, 1991; Beauvois, Bourjade \& Pansu, 1991 ; Beauvois, 1994). A kind of evil that leads to alignment, according to these writers, in favor of the interests of a a business that neglects its employees; it alienates its employees by means of what they call alignment (Aparicio, 2003; 2006 c; $2009 \mathrm{f}$ and g).

The findings on this line complete, from a qualitative level, the current ones in Aparicio, 2005a and 2009c, where Alignment was one of the key variables in relation to subjective and objective Job Attainment. In fact, the aligned individuals - although they freely consent to submission - felt satisfied and they developed fast careers, crowned with the prize of submission. Rise came soon (See Results on the same line in graduates, Aparicio 2005 a; 2006 a and b; 2007a and b; 2009 a, b and c). This is, in our opinion, significant dysfunction. However, it controls business and public working environments. It appears almost as a "necessary evil" to rise and pursuit careers without major opposition or difficulties.

In our work, the most significant and relevant words coming from observation techniques of social representations (hierarchical evocation of J.-C Abric, 2001; Moscovici, 1986; Doise \& Palmonari,1986; Doise, Clemence \& Lorenzi-Cioldi, 1992) expressed their visions about global work world, quite tinged by Negativity and Fatalism, especially observed in France when reference was made to professional (the details of the words used, to which we will not refer for the sake of brevity, can be seen at Aparicio \& Cros, 2015 a)). It is important to point out, too, that the was much difference between the words used by doctors to define the Work World and the Professional Work, somewhat less negative due to the 
connotations of being a professional today and before It will be presented (ibid). [lt will be presented in more extensively in a work in the next conference (EUSER, Hensinski].

\section{Conclusion}

As we can see, the individual (micro level), work organizations (meso level) and the surrounding macro context showed themselves in a self-sustained interplay, not linear, with the view to true development and satisfaction which gives a feeling of fulfillment and "psychological well-being", in addition to the feeling of happiness Mobility may cause.

Findings suggest rethinking, at the institutional (University) and organizational (businesses, and more globally, work world) levels, which competences must be strengthened in order to guarantee a true growth at the professional level of the individuals and of the organizations themselves (Zarifian, 1988); a kind of growth which does not lead to decrease in security, to alignment, to achieving a type of satisfaction "marred" by numerous dimensions; a kind of growth which is not just financial, because globally speaking, the more Mobility, the more Professional Status and the higher pay. Nevertheless, the financial matter does not define Satisfaction. On the contrary, it seems to be seeking development at a human level, lasting development accompanying physical, mental and organizational health.

Rise appears as a conflict issue: there is a price to pay. Aubert \& Gaulejac (1991) have been referring, for the last 20 years, to "the price of excellence", still expending its connotation.

It represents a challenge for trainers, planners, work and organization psychologists, Administration and Management experts in order to prevent physical, psychosocial, and contextual risks for the benefit of quality of life inside and outside of work.

\section{Discussion}

This non-linear relation between Professional Mobility and "lived" Satisfaction, at first sight apparently inconsistent, has been previously found in a work (qualitative level) carried out on researchers and research-teachers who work at the Science Area at the same University and CONICET (National Council of Scientific Research, in Argentina).

The findings may be understood through the distance between the demands of work World when it is in a higher position (in terms of knowledge updating, upgrading, production and transmission, Mobility within a context of increasing internationalization) and available elements, including Material Factors, economic aspects, salaries, administrative factors (number of technical support personnel, micro-management operation, Planning, Supervision/Boss, Atmosphere at work, ...) ; growing Responsibility in connection with the rank in the hierarchical scale, Leadership, collective and social competences not adequately developed, anomy extended into the micro-social level, little expectation for change based on the low credibility in the political system, among other factors. The findings may be understood in the light of the Expectancy-Valence Theory (Weiner, 1980; Feather \& Davenport, 1959, 1981, 1982). From the "expectation" theory, it can be assumed that the most movable subjects (those who have climbed the corporate ladder) tend to have higher expectations once they have reached a high position in the professional pyramid, thus demanding more and more from those leading the system (Weiner, 1980).

Also, this "experienced" Satisfaction may be interpreted in the light on the theory of anomy (Clinard, 1967; Chazel, 1967; Aparicio, 1982, 2014a); a theory developed a century ago, which, considering the present market circumstances, has regained popularity.

Finally, it may also be interpreted in the light of the "consumption/investment" model. From the "investment"-model point of view (Becker, 1964), those who have reached a higher position and made a greater effort towards higher achievements of the group may expect more benefits, many of which are associated to management.

As for the rest, dissatisfaction clearly appears due to the so called "plafond" effects followed by mass Universities: the more high level graduates there are, the more difficult it is to reach the desired position, and if Professional Mobility is known, it is not unusual for the graduates to feel unhappy when confronted to the increasing pressures from a more globalized and competitive Market. In France, the interviewed doctors are less satisfied than those in Argentina (doctorate programs have existed for over 500 years). However, in Argentina, a PhD degree still constitutes an "extra" (particularly in social sciences, 
where the number of doctors is fewer). In addition, this study shows significant Professional Mobility (in one on the courses of study that have been analyzed, said Professional Mobility or rise gets to $70 \%$, even before being awarded the degree).

The Interplay between the individuals in different disciplinary fields and the organizational and macro national contexts appears clearly in this international work.

Finally, the "objective" Status reached in the hierarchical scale does not correlate with what has been "experienced" or "felt" when such Status has been achieved ("lived" Satisfaction at the level of group or individual Psychological-social well-being).

All this is relevant and it shows that salary factors are important, although they are far from being the most valued aspect doctors, who also demand certain conditions for their professional and personal development, within a work climate or atmosphere which favors such development (Payne, 1973) and, especially, socio-professional recognition. This aspect is shown in the study with researchers. Doctors-researchers from both fields feel they are not satisfied with leadership in their teams (Fiedler, 1967; Knorr, Mittermeir, Aichholzer \&. Waller, 1979; Hollander, 1971; Andrews et al., 1979). Also, Recognition, or better, the lack of it appears much more evidently at the level of an unsatisfied need within the French group, although it is also present (due to the recurrence of evocation of the word as well as to the rank of importance assigned to such term) as a relevant issue for Argentines. It would seem to be a "widespread disease" (Aparicio \& Cros, 2015).

To conclude, connected to other articles (Aparicio 2009h; 2015 b; Aparicio, 2012b; 2014 c; 2015 a,b,c,d,e,and f; 2016 a,b,c and d). ), in the interplay between Position and Satisfaction, from a complementary angle, there appears the issue of Identity. In fact, it is the result of a construction between the historical-biographical, personal-socio-cultural and the relational aspects in the professional places for interaction (Sansaulieu, 1977; Courpasson, 1994; Dubar, 2000a, b and c).

\section{References}

[1] Abric, J.-C. (2001). Metodología de recolección de las representaciones sociales In J.-C.Abric (comp.), Prácticas sociales y representaciones, México, Ediciones Coyoacán, 53-74.

[2] Andrews et al. (1979). Scientific Productivity. Cambridge University Press/UNESCO.

[3] Aparicio, M. (1983). La desigualdad de oportunidades. La movilidad social en las sociedades industriales. Traduction R. Boudon, L'inégalité des chances. La mobilité sociale dans les sociétés industrielles. Paris: PUF.

[4] Aparicio, M. (2002a). Movilidad profesional y satisfacción con los líderes grupales en organizaciones académicocientíficas. La Psicología social en México, IX, 665-678.

[5] Aparicio, M. (2002b). La devaluación de los diplomas universitarios y sus efectos sobre el logro académico y profesional. Un análisis a la luz de dos modelos teóricos. Revista de la ULZA, Publicación electrónica.

[6] Aparicio, M. (2003). El Fatalismo y la Alineación. Un estudio en graduados desocupados. $9^{\circ}$ Reunión Nacional de la Asociación Argentina de Ciencias del Comportamiento. International Union os Psychological Science, Córdoba. September.18th-20

[7] Aparicio, M. (2004a). Réussite, exclusion et logiques associées dans le système productif anticipe par le système éducatif. Une analyse à partir du modèle consommation-investissement. La personne et ses rapports au travail, Paris, L'Harmattan, 51-59.

[8] Aparicio, M. (2004b). La psychologie de sous-emploi structurel. Une étude dans des organisations à la lumière de modèles attributionnels. In A. Lancry \& C. Lemoine, La personne et ses rapports au travail, Paris, L'Harmattan, 60-73.

[9] Aparicio, M. (2005a). Les facteurs psychosociaux et la réussite universitaire et professionnelle. PhD. 2d. Thesis. Paris, Sorbonne. Mention : Très honorable avec félicitations du jury á l'unanimité.

[10] Aparicio, M. (2006a). Trayectorias universitarias. Un análisis a la luz de metodologías cuantitativas. Vol I. Mendoza: ZETA, $294 \mathrm{p}$.

[11] Aparicio, M. (2006b). Trayectorias universitarias: Un análisis a la luz de metodologías cualitativas. Vol II. Mendoza: ZETA, 438 p. Aparicio, M. (2007a). Les facteurs psychosociaux à la base de la réussite universitaire et professionnelle: aspects psychologiques et organisationnels. HDR (Psychologie). Université Lille3. 
[12] Aparicio, M. (2006c). L'Allégeance et la réussite dans le monde du travail.14ème Congrès de Psychologie du travail et développement et des organisations. Tunez, July 7 th-10th.

[13] Aparicio, M. (2007b). Mobilité et réussite universitaires et professionnelles. Du niveau macro au niveau micro. HDR (Education). Université París X, Nanterre.

[14] Aparicio, M. (2009a). La demora en los estudios universitarios. Causas desde una perspectiva cuantitativa. Tomo I. Mendoza: EDIUNC.

[15] Aparicio, M. (2009b). La demora en los estudios universitarios. Causas desde una perspectiva cualitativa. Universidad Nacional de Cuyo, Tomo II. Mendoza: EDIUNC.

[16] Aparicio, M. (2009c). Les facteurs psychosociaux et la réussite universitaire et professionnelle. ANRT. Presses de l'ANRT, Lille, 469 p., 126 p. Appendixes.

[17] Aparicio, M. (2009d). Conference. Congrès de l'Ecole de Gestion: Nouvelles carrières. Nouvelles compétences. Les trajectoires universitaires et professionnelles: entre formation et travail, Faculté des Sciences de la gestion, Université de Rouen, May 13 th- 14

[18] Aparicio, M. et al (2009e). I Congrès de l'Ecole de Gestion: Nouvelles carrières. Nouvelles compétences. Transformations du travail: nouvelles problématiques, nouveau enjeux. Rouen: Université de Rouen. May 13 th-14.

[19] Aparicio, M. et al (2009f). I. Congrès de l'École de Gestion: Nouvelles carrières. Nouvelles compétences. Les cultures universitaires et organisationnelles et son impact sur l'insertion dans le monde du travail. Rouen: Université de Rouen. May 13th-14. APARICIO. M. (2009). Alineación y el logro en el Mundo del Trabajo. XXXII Congreso Interamericano de Psicología: un camino hacia la paz y la democracia. Guatemala: Universidad del Valle de Guatemala, June 28th-July 2th.

[20] Aparicio. M. (2009g). Internalidad, Alineación y Movilidad profesional. XXXII Congreso Interamericano de Psicología: un camino hacia la paz y la democracia. Guatemala: Universidad del Valle de Guatemala, June 28th-July 2th.

[21] Aparicio, M. (2009h). "Identity, Values and Culture Organizational. A Study within Scientific Organizations". 11th European Congress of Psychology ECP09. Oslo University. Oslo, July, 7th-10th.

[22] Aparicio, M. (2012). Trajectoires universitaires/professionnelles et identité. In: J. Clénet, Ph. Maubant \& D. Poisson (Eds.). Formations et professionnalisations: à l'épreuve de la complexité. Paris: L'Harmattan, 195-229.

[23] Aparicio, M. (2012 b). Institutional Identity and the Role of Gender as News Filter.115th Annual Convention of the American Psychological Association, Orlando, USA, July 2012.

[24] Aparicio, M. (2014a). Satisfaction, Professional Mobility and Leadership in Academic-Scientific Organizations, Journal of Health Science, 2(3), 135-145.

[25] Aparicio, M. (2014b). Postgraduate Level and its Impact on Academic Studies and Professional Careers, Social and Job Mobility and Identity. A Study about PhD Graduates and PhD Students at UNCuyo, in the Light of a sui generis Paradigm, Journal of Educational and Social Research, 4(2), Special Issue - April.

[26] Aparicio, M. \& Rodríguez, G. (2014c). "University Performance, Achievement, Institutional Identities and Professionalization. END - International Conference on Education and New Developments 2014. June 28th-30th. Madrid, Spain.

[27] Aparicio, M. \& Cros, F. (2015a). Trajectoires et identités. Un avenir incertain pour les docteurs? Paris: L'Harmattan. Collection Education et Sociétés.

[28] Aparicio, M. (2015d). Identity, Weakening and Professionalization: A Study of Graduate and Postgraduate Students (1987-2002) in the Light of the Three-Dimensional Spiral of Sense Theory In A.M. Silva \& M. Aparicio, International Handbook of Professional Identities, Scientific and Academic Publishing, 131-156.

[29] Aparicio, M. (2015 e). Towards a sui generis systemic theory: The Three-Dimensional Spiral of Sense. A Study in Argentina Applied to Identity and Professionalisation (Article 1). Asian Academic Research Journal of Social Sciences \& Humanities (AARJSH), vol 2, issue 7 (December 2015), 246-282.

[30] Aparicio, M. (2015 f). The Theory of the Three-Dimensional Spiral of Sense: An Application with special Reference to Identity and Professionalisation in other Disciplinary Areas (Article 2) Asian Academic Research Journal of Social Sciences \& Humanities (AARJSH), vol 2, issue 7 (December 2015), 194-245. 
[31] Aparicio, M. (2016a). "The Three Dimensional Spiral of Sense: A New Paradigm Systemic Applied a Six Areas Disciplinary and Two Axes: Identity and Professionalization". 8th International Conference on Social Sciences (ICSS), March, 4th-5th, Sofia. Book of Proocedings.

[32] Aparicio, M. (2016b). Homogenization and Mass Identity vs. Individual Identity. Un Analysis at the Light of a New Theory: The Three Dimensional Spiral of Sense. 8th International Conference on Social Sciences (ICSS), March, 4th-5th, Sofia. Book of Proocedings.

[33] Aparicio, M. (2016c). Resiliency, Professionalization and Identity. A study in relation to Achievement at University at the light of a new Paradigm: The Spiral of Three Dimensional of Sense). 9th International Conference on Social Sciences (ICSS), April, 8th-9th, Dubrovnik, Croacia. Book of Proocedings.

[34] Aparicio, M. (2016d). "Barriers to Learning, Achievement, Institutional Identities and Professionalization". 9th International Conference on Social Sciences (ICSS), April, 8th-9th, Dubrovnik, Croacia. Book of Proocedings.

[35] Argyris, C. \& Schön, D. (1974). Theory in Practice. Harvard University /Cambridge, Massachussets.

[36] Argyris, C. \& Schön, D. (1978).Organizational Learning. Harvard University /Cambridge, Massachussets.

[37] Argyris, C. \& Schön, D. (1996a). Organizational Learning II. Harvard University /Cambridge, Massachussets.

[38] Argyris, C.\& Schön, D. (1996b). Theories of action, double-loop learning and organizational learning. Harvard University /Cambridge, Massachussets.

[39] Bourdoncle, R. (1993). La professionnalisation des enseignants: les limites d'un mythe, Revue française de pédagogie, 105, 83-119.

[40] Bourdoncle, R. \& Demailly, L. (1998) (comp.). Les professions de l'éducation et de la formation. Paris: Septentrion.

[41] Calmand J. \& Haller P. (2008). Etre diplômé de l'enseignement supérieur, un atout pour entrer dans la vie active, Bref, $n^{\circ} 253$.

[42] Aubert, N. \& Gaulejac, V. de (1991). Le coût de l'excellence. Paris : Seuil.

[43] Aubret, J. \& Gilbert, P. (1997). Psychologie de la ressource humaine. Paris: PUF.

[44] Beauvois, J.L. \& Joule, R.V. (1981). Soumission et idéologies. Psychosociologie de la rationalisation. Paris : PUF. Cité par J.L. Beauvois, La servitude libérale, Paris, Dunod, 1984.

[45] Beauvois, J.L. (1991). Faut-il renoncer au recrutement. Revue Internationale de Psychologie Sociale, 4, 1-2, 187-189.

[46] Beauvois, J.L. (1994). Traité de la servitude libérale. Paris : Dunod.

[47] Beauvois, J.L., Bourjade, A. \& Pansu, P. (1991). Norme d'internalité et évaluation professionnelle. Revue Internationale de Psychologie Sociale, 4, 1-2, 9-28.

[48] Becker, G. (1964). Human Capital. New York: National Bureau of Economic Research. Traduction espagnol: El capital humano, Madrid, Alianza, 1983.

[49] Brunet, L., et Savoie, A. (1999). Le climat de travail. Outremont, Qc.: Les éditions Logiques.

[50] Calmand, J. \& Haller, P. (2004). Etre diplomé de l'enseignement supérieur. Un atout pour entrer dans la vie active. Bref, 253, June.

[51] Castra, D. (1998). Mécanismes implicites de prises de décision dans la situation de recrutement. L'orientation scolaire et professionnelle, 24, 2, 115-133.

[52] Castra, D. (1998). Internalité et exclusion sociale. Les Cahiers Internationaux de Psychologie Sociale, 37, 45-62.

[53] Courcy, F., Harvey, S., Marceau, A.; Rochon, A. \& Belleau, B. (2006). Climat de travail et épuisement professionnel: examen du rôle médiateur de la violence. Actes. 14e Congrès de psychologie du travail et des organisations, Hammamet, Tunisie.

[54] Courpasson, D. (1994). Marché concret et identité professionnelle locale. La construction de l'identité par le rapport au marché. R. Française de Sociol., 35, 2, 197-229.

[55] Coutrot, L. \& Dubar, C. (1992). Cheminements professionnels et mobilité sociale. Paris : La Documentation Française. 
[56] Cueillens, C. (1998). Normes d'internalité et d'individualisme dans les conduites sociales d'évaluation. Thèse de Doctorat, Université Bordeaux 2.

[57] Chauvot, P. (1997). L'attribution de l'échec chez les cadres. L'orientation scolaire et professionnelle, 26, 4, 527-557.

[58] Chazel, F. (1967). Considérations sur la nature de l'anomie. R. Française de Sociol., 8, 515-568.

[59] Doise, W. \& Palmonari, A. (Eds.) (1986). L'étude des représentations sociales. Neuchâtel: Delachaux et Niestlé.

[60] Doise, W., Clemence, A. \& Lorenzi-Cioldi (1992). Représentations sociales et analyse de données. Grenoble: Presses Universitaires de Grenoble.

[61] Dubar, C. (2000a). La socialisation. Paris: Armand Colin.

[62] Dubar, C. (2000b). La formation professionnelle permanente. Paris: La Découverte.

[63] Dubar, C. (2000c). La crise des identités. Paris: PUF.

[64] Dubois, N. (1994). La norme d'internalité et le libéralisme. Grenoble: Presses Universitaires de Grenoble.

[65] Dupray A. \& Moullet S. (2004). Femmes à l'entrée dans la vie active: un retard salarial en partie inexpliqué, NEF, $n^{\circ}$ 12.

[66] Dupray A. (2005). Les mobilités en début de la vie professionnelle. Externes ou internes aux entreprises, des évolutions aux effets très différents, Bref, $n^{\circ} 216$.

[67] Enriquez, E. (1976), Évaluation des hommes et structures d'organisation des entreprises. Connexions, 19, 79-110.

[68] Enriquez, E. (1989). L'individu pris au piège de la structure stratégique. Connexions, 54(2), 145-161.

[69] Feather, N.T. (1959). Subjective Probability and Decision under Uncertainty. Psychological Review, 66, 150-164.

[70] Feather, N. \& Davenport, P. (1981). Unemployment and Depressive Effect: A Motivational and Attributional Analysis. Journal of Personality and Social Psychology, 41(3), 422-436.

[71] Feather, N. \& Davenport, P. (1982). Desempleo y sentimiento depresivo: Un análisis motivacional y atributivo. Estudios de Psicología, 12, 63-81.

[72] Fiedler, F. (1967). A Theory of Leadership Effectiveness. New York: McGraw-Hill.

[73] Gilbert, P. (2003). La gestion previsionnelle des ressources humaines. Paris: La Découverte.

[74] Gilbert, P. (2004). L'instrumentation de la gestion. Paris: Economica.

[75] Giret, J.-F. (2003). Parcours étudiant : De l'enseignement supérieur au marché du travail. Relief, 1.

[76] Giret J.-F, Moullet S. \& Thomas G. (2003). De l'enseignement supérieur à l'emploi: les trois premières années de vie active de la Génération 98 . Enquête " Génération 98 ", NEF, n4.

[77] Giret J.-F. (2003). Parcours étudiants: de l'enseignement supérieur au marché de travail, Céreq/GTES, Relief, $n^{\circ} 1$.

[78] Hertzberg, F., Mausner, B. \& Snyderman, B.B. (1959). The Motivation to Work. New York: Wiley \& Sons.

[79] Hollander, E. (1971). Style, Structure and Setting in Organizational Leadership. Administrative Science Quaterly, 16, 1, 1-19.

[80] Knorr, K., R. Mittermeir, G. Aichholzer \&. Waller, G. (1979). Leadership and Group Perfomance. In F. Andrews, op. cit., $55-120$.

[81] Louche, C. (1998). The Norm of Internality and Coordination Mechanisms in Organizations. Revue Européenne de Psychologie Appliquée, 48(3), 189-192.

[82] Louche, C. (1992). Structure des organisations et norme d'internalité : une étude exploratoire. Univ. de Montpellier III, Labo. de Psych. Soc.

[83] Luminet, O. (1996). La norme d'internalité dans la consultance en recrutement. Variations et clairvoyance dans l'emploi des critères attributifs. Revue Internationale de Psychologie Sociale, 1, 69-89.

[84] McClelland, D. (1961). The Achieving Society. Princeton: Van Nostrand Company, Inc. 
[85] McClelland, D. (1970). El impulso a la modernización. Facetas, 3(4), 60-70.

[86] Clinard, M. (1967). Anomia y conducta desviada. Buenos Aires: Paidós.

[87] Moscovici, S. (1986). L'ère des représentations sociales. In: W. Doise \& A. Palmonari (Eds.), L'étude des représentations sociales, Neuchâtel, Delachaux et Niestlé.

[88] Nicole-Drancourt, Ch. (1994). Mesurer l'insertion professionnelle. R. Française de Sociol., 35, 1,37-69.

[89] Parker, C. P., Baltes, B. B., Young, S. A., Huff, J. W., Altmann, R. A., Lacost, H. A. et Roberts, J. E. (2003). Relationships between psychological climate perceptions and work outcomes: a meta-analytic review. Journal of Organizational Behavior, 24, 389-416.

[90] Payne, R. (1973). Relationships of Perception of Organizational Climate to Organizational Structure, Context and Hierarchical Positions. Administrative Science Quality, 18, 515-526.

[91] Reynaud, B. (1992). Le salaire, la règle et le marché. Paris: Bourgois.

[92] Rochon. A. \& Courcy, F. (2006). Le rôle du climat de travail dans la prédiction de la violence psychologique. Actes. 14e Congrès de psychologie du travail et des organisations, Hammamet, Tunisie.

[93] Rosen, B.C. (1956). The Achievement Syndrome. Amer. Sociol. Rev., 21, 203-211.

[94] Sansaulieu, R. (1977). L'identité au travail. L'apprentissage culturel en organisation. Presses de la FNSP, $2^{a}$ ed., 1995.

[95] Silva, A.M. \& Aparicio, M. (Comp.) (2015 b). International Handbook about Professional Identities. USA: Publishing Editors.

[96] Silva, A.M. \& Aparicio, M. (Comp.). (2015c). Introduction. In A.M. Silva \& M. Aparicio (Comp.) International Handbook about Professional Identities. USA: Publishing Editors.

[97] Stankiewicz, E. (Ed.). Les stratégies d'entreprises face aux ressources humaines. Paris : Economica.

[98] Weiner, B. (1985). An Attributional Theory of Achievement Motivation and Emotion. Psychological Review, 92, 4, 548573.

[99] Zarifian, P. (1988). L'émergence du modèle de la compétence. In E. Stankiewicz (Ed.). Les stratégies d'entreprises face aux ressources humaines, Paris, Economica. 